\title{
Dociekania
}

\section{Autonarracja jako strategia negocjowania tożsamości w tekstach polskich migrantów przebywających w Wielkiej Brytanii i Irlandii po roku 2004}

Joanna Ślósarska

TEKSTY DRUGIE 2016, NR 3, S. 273-287

DOl: $10.18318 /$ td.2016.3.15

A utonarracja to podstawowa forma wypowiedzi polskich autorów migracyjnych przebywających po 2004 roku w Wielkiej Brytanii i Irlandii. Preferowana przez nich forma wypowiedzi to epicki dziennik z podróży w zróżnicowanych kompozycyjnie i stylistycznie odmianach gatunkowych powieści, opowiadań, esejów, reportaży. Autorami i narratorami tekstów (kształtowanych najczęściej za pośrednictwem narracji pierwszoosobowej) stali się absolwenci studiów humanistycznych (polonistyki, filozofii, dziennikarstwa i komunikacji społecznej, marketingu i zarządzania), a także osoby z wykształceniem zawodowym - hotelarze, pielęgniarki, właściciele małych firm, sprzedawcy, leśnicy, geolodzy. Na migracyjną twórczość otworzyły się w Polsce liczne wydawnictwa, również niszowe, konstruując specyficzne interakcyjne pole literackie między rodzącą się w Wielkiej Brytanii i Irlandii „narracyjną communitas” a twórcami i odbiorcami w rodzimym, opuszczonym czasowo środowisku.

Podejmowane przez migracyjnych autorów tematy koncentrują się wokół wymiany relacji „swój/obcy” na
Joanna

Ślósarska - prof. dr hab., kierownik Pracowni Antropologii Literatury Ut, pracownik Katedry Teorii Literatury w Instytucie Kultury Współczesnej Ut. Ostatnio opublikowała ksiązki: Skrypty losu (2015), Zasada tranzytywności w kulturze (2014), Łapacze snów Ponowoczesne kody spóiności kulturowej (2012). Kontakt: joannas@uni.lodz.p 
relację "ustabilizowany/nieustabilizowany" w ramach społecznych i ekonomicznych uwarunkowań w nowych miejscach zamieszkania. W konstrukcje narratorów i bohaterów, jako podmiotów kreujących obrazy owych miejsc, wpisywane są poszukiwania nowych, indywidualnych tożsamości oraz tożsamości wspólnotowych, mających służyć ustanawianiu niezbędnego współczynnika stabilizacji. Procesy te w literackich przedstawieniach mają charakter redeskrypcji symbolicznego świata znaczeń, zwłaszcza w zakresie interakcji na różnych poziomach komunikacji zbiorowej i w różnych, w tym wartościujących odniesieniach do rzeczywistości społecznej, które Herbert Blumer rozpatrywał w koncepcji interakcjonizmu symbolicznego'. Z tym problemem łączy się w autonarracjach tematyczna eksploracja egzystencjalnych sytuacji kryzysowych oraz kształtowanie progresywnych, twórczych biografii w miejsce ,trajektorii cierpienia"2. Konstruowanie literackich autonarracji (często niewiązane z umiejętnościami literackimi) to jedna z istotnych strategii egzystencjalnych, włączanych w rytm codzienności przez polskich migrantów. Hipotezy interakcjonizmu symbolicznego oraz strategii biograficznych w połączeniu z programem badań nad narracją jako sposobem poznawania i rozumienia świata ${ }^{3}$ umoźliwiają pełniejsze rozpoznawanie intensywnie rozwijającej się po 2004 roku polskiej twórczości migracyjnej.

\section{Narracje o negocjowaniu tożsamości w niestabilnych sytuacjach interak- cyjnych w wybranych tekstach polskich migrantów}

Problematykę tożsamości ustanawiają autorzy tekstów migracyjnych w trzech zakresach: społecznym, biograficznym i aksjologicznym. W zakresie społecznym eksponowane jest napięcie między ukształtowaną kulturowo tożsamością etniczną (opuszczoną i aktualną wspólnotą lokalną) i początkowo niezbyt czytelną dla migrantów nową wspólnotą, której kody organizacji pola społecznego są stopniowo (wraz z przyswajaniem języka) rozpoznawane. W zakresie biograficznym najczęstsze motywy eksponowane w światach przedstawianych reprezentują doświadczenia niezgodności nabytych

1 H. Blumer Interakcjonizm symboliczny, przeł. G. Woroniecka, Nomos, Kraków 2007.

2 F. Schütze Trajektorie cierpienia jako przedmiot badań socjologii interpretatywnej, przeł. M. Czyżewski, „Studia Socjologiczne" $1997 \mathrm{nr}$ 1, s. 11-56.

3 J. Trzebiński Narracyine konstruowanie rzeczywistości, w: Narracja jako sposób konstruowania świata, red. J. Trzebiński, GWP, Gdańsk 2002, s. 21-31. 
w rodzimym środowisku zdolności adaptacyjnych i oczekiwań z warunkami, w jakich migranci mogą w ogóle rozpocząć swoją aktywność. To warunki wybierają ich, a nie oni owe warunki. Wybór między różnorodnymi sposobami działania i pokonywanie progu alokacji są z konieczności regulowane przez komponent pragmatyczny, sprowadzany do skuteczności walki o przetrwanie. Komponent ten stanowi również wstępnie zakładany, doraźny cel wyjazdu („uskładanie upragnionego tysiąca funtów”), co wymusza nadzwyczajną wrażliwość na szybko zmieniające się okoliczności: „na emigracji fortuna bywa niesamowicie przekorna”, „drobna chwila, głupie kilka sekund może diametralnie odmienić ludzki los i to w najmniej oczekiwanym momencie"4. W narracjach sytuacje „bycia wybieranym przez warunki” nawarstwiają się i krzyżują równocześnie z doświadczeniami naruszania granic indywidualnej tożsamości związanej z uzyskanym wcześniej statusem społecznym i rodzinnym. Wraz z konieczną w nowej przestrzeni akceptacją namiastki domu w sensie materialnym (symboliczna, ,obskurna kanciapa nad kebab barem” zamieszkiwana przez czterech kumpli5) w opowieściach rozwija się temat aksjologicznej obrony „domu wewnętrznego”, stanowiącego o zachowaniu godności i więzi z wcześniejszym „ja”. Problem narracyjnej reorientacji wzorów biografii i postaw w odniesieniu do zmiennych okoliczności to fragment dokonującej się w kulturze migrantów rekonstrukcji strukturalnych rozróżnień, w ramach których w polu społecznym zostały uprzednio nacechowane pozycje mające stanowić o habitusie podmiotu. Choć ze względu na napięcie między obiektywnym i subiektywnym aspektem tożsamości psychologiczny aspekt tożsamości ustępuje aspektowi społecznemu, to w opowieściach istotne stają się sposoby wartościującego odnoszenia się do zdarzeń, kształtowania relacji z innymi ludźmi, modelowania progu wraźliwości i oceny faktów. Podobnie jest w przypadku przyjmowanych wcześniej rozgraniczeń własnych emocji i pragnień od nastawień wspólnoty środowiskowej (zwłaszcza gdy dąży ona do realizacji podobnych postaw i celów). Choć tracą one skuteczność, to nie zaciera się jednak radykalnie świadomość toźsamości jednostkowej, kreowanej jako wizja własnej biografii, co podkreślają Piotr Czerwiński, Ireneusz Gębski i Jakub Bolec. W powieści Czerwińskiego Przebiegum życiae czyli kartonowa sieć narrator, dokonując deziluzji Londynu jako migracyjnej „ziemi obiecanej”, interpretuje swoje wcześniejsze oczekiwania jako obrazki z komiksowej utopii: „to było moje rysunkowe miasto, moje magiczne

4 A. Miklasz Polska szkoła boksu. Powieść emigracyina, Skrzat, Kraków 2009, s. 27.

5 Tamże, S. 25. 
tajne miasto, które nigdy nie istniało. Nasze serca były pełne prawdziwej, rysunkowej nadziei”. Rozpoznanie to nie oznacza porzucenia „rysunkowej nadziei", lecz poszukiwanie nowych możliwości jej realizacji w zastanych warunkach społecznych. W powieści Gębskiego W cieniu Sheratona, metonimia Anglii jako „morza cegieł, asfaltu i betonu"7 jest redeskrypcją i osądem nowej przestrzeni, nadal jednak pozostającej obietnicą terytorium, w którym możliwe jest spełnienie marzeń o sukcesie materialnym. W interpretacji Jakuba Bolca, autora opowiadania Zmartwychwstanie śmieciarzy, w fantazmatycznej wizji lotu nad miastem Londyn odsłania się jako płonące światłami „wysypisko", na którym żyją i „zmartwychwstają śmieciarze”, w tym słowiańscy nomadzi ${ }^{8}$, których Adam Miklasz w powieści Polska szkoła boksu określił jako "nową rasę Eastern European” . "Rasa” ta w sarkastycznej konstatacji Piotra Czerwińskiego to „zgraja jednej osoby, która dostała jednego wspólnego kopa w dupę"10.

Gdy tożsamość jednostkowa, zbudowana na doświadczeniu ciągłości własnej biografii, zostaje podważona, poczucie teraźniejszej, wewnętrznej spójności również ulega rozbiciu i fragmentacji. Stan napięcia między wewnętrznym obrazem ,ja” i obrazem kształtowanym przez warunki nowego środowiska podtrzymuje z negatywnym skutkiem konieczność zmiany pracy i przyjmowania ofert poniżej zdobytych kwalifikacji. Wykonywane przez polskich migrantów z wyższym, humanistycznym wykształceniem zawody to często prace sprzątaczy, hotelarzy, kucharzy, opiekunek dzieci i osób starszych, sprzedawców, obsługi w pubach"1.

Iwona Słabuszews ka-Krauze w powieści Hotel Irlandia, podejmując temat utraty tożsamości, pisze: „Nie jestem tą o sobą, którą powinnam być. Nie tam, gdzie trzeba być. Nie tak, jak trzeba być"12. W jej autonarracji istotne są

6 P. Czerwiński Przebiegum życiae czyli kartonowa sieć, Świat Książki, Warszawa 2009, s. 335.

7 I. Gębski W cieniu Sheratona, Warszawska Firma Wydawnicza, Warszawa 2011, s. 17.

8 J. Bolec Zmartwychwstanie śmieciarzy, w: Na końcu świata napisane. Autoportret współczesnej polskiejemigracii, Konkurs Literacki Polish Books, Videograf II, Londyn-Chorzów 2007, s. 106.

9 A. Miklasz Polska szkoła boksu..., s. 25.

10 P. Czerwiński Przebiegum życiae..., s. 164.

11 P. Dana-White w powieści Emigrantka z wyboru. Opowieść londyńska, Videograf II, Katowice 2008, s. 10, mówi o standar dowej wśród migrantów "zamianie kompetencji intelektualnych na miotłę i łopatę".

12 I. Słabuszewska-Krauze Hotel Irlandia, Semper, Warszawa 2006, s. 23. 
także dwa inne, również stałe motywy prozy migracyjnej - niewspółmierności rzeczywistości wewnętrznej i zewnętrznej oraz zakłócenia relacji do najbliższego otoczenia. Słabuszewska-Krauze podkreśla w swoich fabułach, że brak autonomii i jakichkolwiek możliwości spełniania potencjału decyzyjnego w polu społecznym przekłada się na walkę o jakość sytuacji lokalnych w spontanicznych wspólnotach. Są to obrazy ochrony granic egoterytorialności w zakresie niekiedy najdrobniejszych rozszerzeń i stabilizacji granic „mojego świata" wobec mikroświata innych, choćby w formie zastrzeżonej półki w łazience czy osobistych naczyn' ${ }^{13}$. Jak podkreśla Marek Butrym w analizie postaw młodych emigrantów zarobkowych, wspólne lub bliskie mieszkania, sieć stosunków, więzi i zobowiązań tworzy specyficzne wspólnoty sprzyjające poczuciu bezpieczeństwa emocjonalnego i fizycznego. Równocześnie jednak sieć owa stymuluje sytuacje konfliktowe, podważa także solidarność etniczną ze względu na chęć pozyskania tych samych dóbr ${ }^{14}$. Praktyka odróżnienia się, znalezienia własnego mieszkania, partnera, a także własnej ekspresji („mojego gło su” wobec „cudzych głosów”) staje się więc konieczna dla ustanowienia i podtrzymywania dezintegrowanego codziennymi okolicznościami wizerunku ,ja”.

Negatywne czynniki w sytuacjach tranzytywnych to niepowodzenia projektów działań, rozpad wspólnotowej samoorganizacji, zakłócenia relacji między tożsamościami osobistymi i tożsamościami małych communitas oraz między owymi wspólnotami i kolektywnymi tożsamościami dużych grup społecznych (etnicznych, organizacyjnych, państwowych) ${ }^{\mathbf{1 5}}$. Niekorzystnie rozwijająca się trajektoria życia prowadzi najczęściej do usunięcia

13 Tamże, s. 113, 143.

14 M. Butrym Kapitał społeczny i stosunek do ojczyzny młodych emigrantów zarobkowych, w: Wielka emigracja zarobkowa młodzieży. Wyzwanie dla edukacji, red. R. Bera, Wydawnictwo UMCS, Lublin 2010, s. 125-132.

15 Strategie przeciwdziałania takim tendencjom po 2004 roku są widoczne w ekspansywnośc wszelkich wspólnot polonijnych w Wielkiej Brytanii (np. Zjednoczenie Polskie w Wielkiej Brytanii, Polish Professionals in London, Polish Psychologists' Club, London Polish Society, Polish deConstruction, Polska Macierz Szkolna, Polonia Nottingham, Europejska Unia Wspólnot Polonijnych) oraz w Irlandii, gdzie rozwinęło się kilkadziesiąt niekiedy wyłącznie lokalnych instytucji skupiających polskich migrantów. Istotną funkcję przeciwdziałania procesom rozpadu wspólnot pełnią także systemy zabezpieczeń: firmy usługowe, doradcze, transportowe, agencje pośrednictwa pracy, insty tucje kulturalne i społeczne, portale internetowe. Zob. Polish Emigration in Ireland in the 20 th and early 21 st Centuries. Polska emigracja w Irlandii w XX ina poczatku XXI wieku, red. I. Płachecki, Wydawnictwo Naukowe Instytutu Technologii Eksploatacji, Dublin-Żyrardów 2012, S. 121-139. 
moralnego wymiaru działań ${ }^{16}$. Wyraziście i z ironicznym dystansem podkreślił to narrator powieści Czerwińskiego, pisząc, że życie zmusza migranta do ucieczki przed sobą samym, do odgrywania nowych, diametralnie odmiennych ról społecznych, symbolizowanych figurami „księcia” i „żebraka”. „Czy byłem silny, czy byłem słaby? - pyta narrator. Pewnie, że tak. Czy byłem chamem? Jasne, oczywiście. Czy byłem dobrym człowiekiem? Czekaj, niech się zastanowię"17.

Podstawowy system wartości pragmatycznych, akceptowany, a zarazem silnie podważany i krytykowany w polskiej literaturze migracyjnej ${ }^{18}$, łączony jest z dążeniem bohaterów do zajęcia odpowiednio dla nich wysokiej pozycji w hierarchii społecznej, co wiąże się zazwyczaj z próbami zdobycia stałej i wartościowej pracy, najlepiej zgodnej z kompetencjami zawodowymi. Utożsamianie komponentu pragmatycznego z prestiżem społecznym prowadzi w początkowej fazie doświadczeń migracyjnych do nadawania nadwyżki znaczeń dobrom konsumpcyjnym, statusowi ekonomicznemu, zdobywaniu pieniędzy. Strategiom osiągania owych wartości towarzyszy często nastawienie hedonistyczne. Poszukiwanie przyjemności stanowi rodzaj kompensacyjnej regulacji napięć i konfliktów, niwelacji przykrych stanów, chwilowego przynajmniej doświadczania życia bez lęku i upokorzeń. Zaangażowanie emocjonalne wyraża się w opisach łatwego odblokowywania stanów uniesień i szczęścia. Stany te intensywnie powtarzają się czy teź raczej są podświadomie odtwarzane w tendencjach do wiązania się z różnymi osobami, bowiem związki takie, nawet przygodne, dają poczucie głębszych, wspólnotowych więzi' ${ }^{19}$.

Jednak satysfakcja ze zdobycia dóbr ekonomicznych nie stanowi zdaniem polskich autorów źródła siły i poczucia własnej wartości. Konieczność funkcjonalnej adaptacji do nowego otoczenia obnaża mechanizm deprecjacji

16 F. Schütze Trajektorie cierpienia, s 140-145.

17 P. Czerwiński Przebiegum życiae..., s. 272.

18 Przecenianie dóbr konsumpcyjnych to często efekt importowanej z kraju wyjazdu ideologii sukcesu, charakterystycznej dla ubogich państw poakcesyjnych. Na ten temat Magdalena Zimny-Louis w powieści Ślady hamowania, Replika, Zakrzewo 2011, s. 112 w ironicznej kliszy pisze z takiej właśnie, poakcesyjnej perspektywy: „Mam nadzieję, że masz najnowszy telefon komórkowy, markowe ciuchy, drogi zegarek i foto jakiegoś luksusowego auta, jakim jeździsz po Stanach, bez tego wszyscy uznają, że ci się w życiu nie udało".

19 Doświadczenia takie podtrzymują pozytywne nastawienie i w efekcie prowadzą do satysfakcjonującej stabilizacji losu, jak w powieściach A. Bednarskiej Emigracja uczuć, Replika, Zakrzewo 2012, oraz A. Martynowskiej Karpie, łabędzie i Big Ben, Sonia Draga, Katowice 2010. 
postawy allocentrycznej we współczesnym, zróżnicowanym ekonomicznie i kulturowo środowisku społecznym, ujednolicanym jednak i sterowanym przez indukowanie nadwyżki potrzeb i ich komercjalizację. W efekcie marginalizowane jest postrzeganie innego człowieka jako podstawowej, autonomicznej wartości. Wyraziste rozpoznanie owego efektu jest jednym z podstawowych wyznaczników rekonstruowania wewnętrznego poczucia tożsamości bohaterów tekstów migracyjnych. W perspektywie przesłanek interakcjonizmu symbolicznego, sformułowanych przez Herberta Blumera, proces ten można interpretować jako aksjologiczną regulację świata znaczeń. „Przesłanka pierwsza mówi, że istoty ludzkie działają wobec przedmiotów na podstawie znaczeń, jakie te przedmioty dla nich mają. Owe przedmioty to wszystko, co człowiek może spostrzec w swoim świecie - obiekty fizyczne, takie jak drzewa czy krzesła; inne istoty ludzkie, takie jak matka czy ekspedient; kategorie ludzi, takie jak przyjaciele lub wrogowie; instytucje, takie jak szkoła czy rząd; ideały, takie jak niezależność jednostki czy uczciwość; działania innych, takie jak polecenia lub prośby, a także wszelkie sytuacje, jakie jednostka spotyka na co dzień. Zgodnie z drugą przesłanką, znaczenia takich przedmiotów wywodzą się z interakcji społecznych, jakie łączą jednostkę z jej otoczeniem. W myśl trzeciej przesłanki ludzie posługują się tymi znaczeniami i modyfikują je w procesach interpretacji, jakim poddają napotykane przedmioty"20.

Skrajnie blokowane przez bariery ekonomiczne i komunikacyjne możliwości uzgodnienia subiektywnego (także lokalnie wspólnotowego) świata znaczeń z egzystencjalnymi praktykami codzienności sprawia, że dynamika jakościowa szlaku życia może stać się zbiorem kolejnych pułapek. Formułując pojęcie biograficznych trajektorii, Fritz Schütze podkreślał, że charakterystyczną cechą dynamiki jakościowej danego szlaku jest w pewnym momencie nieuchronność określonych zdarzeń, rozwijających się na bazie zbioru i potencjału faktów początkowych. Jeśli wydarzenia i ich ramowe warunki prowadzą do załamania oczekiwań, wówczas jednostki i wspólnoty zaczynają pogrążać się w narastającym chaosie informacji i zdarzeń. Doświadczenie to może mieć silną podstawę w warunkach zewnętrznych, obiektywnych, ale także może wynikać z rozpadu indywidualnego, symbolicznego uniwersum. W tekstach polskich imigrantów trajektorie takie (tzw. trajektorie cierpienia) odsłaniane są w obrazach i opisach postępującego negatywnie procesu (toru, kierunku, szlaku, akcji), w którym dominuje powtarzalność 
doświadczeń poniżenia i utraty godności oraz wszelkich zaburzeń emocjonalnych, wynikających z braku pozytywnych interakcji. Jednym z zasadniczych, literackich gestów obronnych w prozie migracyjnej staje się wówczas sarkastyczna ironia, pełniąca doraźnie lub długoterminowo istotną funkcję działania renormalizacyjnego, jak w prozie Piotra Czerwińskiego i Marcina Wojnarowskiego ${ }^{21}$.

\section{Funkcja autonarracji w strategiach negocjowania tożsamości w tekstach polskich migrantów}

Problem negocjowania tożsamości przez konstruowanie opowieści to aktualnie fragment szerszego dyskursu społecznego, rozwijanego na styku badań socjologicznych, politycznych, ekonomicznych, psychologicznych i literaturoznawczych. George A. Akerlof i Robert J. Shiller konstruują ów dyskurs w ramach ponowoczesnych ujęć globalnej gospodarki i ludzkiej przedsiębiorczości. Zdaniem autorów Zwierzęcych instynktów opowieści stanowią "motor ludzkiego działania"22. "Potęga opowieści” tkwi w budowaniu pewności siebie jednostek i wspólnot, budowaniu najlepszych skryptów i scenariuszy działania w określonych warunkach środowiska oraz przekraczaniu zasady zbierania anegdot w kierunku kompozycyjnych całości, odzwierciedlających plany przyszłego, skutecznego działania ${ }^{23}$.

W prozie polskich migrantów wyraźne są dwie podstawowe strategie autonarracyjne. Pierwsza $z$ nich to reprezentacje indywidualnych, a zarazem skryptowych trajektorii biograficznych, nastawionych na zmianę modelu życia zawodowego, emocjonalnego i rodzinnego. Druga to zasada odrzucania anegdot na rzecz konstruowania progresywnych modeli akcji, wyrażana za pośrednictwem kompozycji, a zwłaszcza „szczęśliwego zakończenia”, którym może być niekiedy ustabilizowanie dochodów, zastrzyk gotówki od pracodawczyni, gospodyni lub właścicielki wynajmowanego mieszkania, dobry, wzmacniający poczucie bezpieczeństwa i wartości życia związek uczuciowy

\footnotetext{
21 M. Wojnarowski Okrutny idiota albo prywatnyżart, ER, Poznań 2008.

22 G.A. Akerlof, R.J. Shiller Zwierzęce instynkty. Czy ludzka psychika napędza globaing gospodarkę ijaki to ma wpływ na przemiany światowego kapitalizmu, przeł. I. Jannasz, Wydawnictwo Studio EMKA, Warszawa 2010, s. 78.

23 Tamże, s. 77-84
} 
i partnerski, narzeczeństwo ${ }^{24}$. Dająca poczucie wewnętrznego bezpieczeństwa strategia progresywnej kompozycji umożliwia wprowadzanie różnorodnych negatywnych emocji i codziennych okoliczności, które w ramach strukturalnego chwytu organizacji całości spełniają jedynie funkcję ekspozycji barier, progów doświadczeniowych i komunikacyjnych. Charakterystyczne w narracjach polskich migrantów przechodzenie od transakcyjnej, inwestycyjnej koncepcji biografii do sformułowania projektu biografii transformacyjnej, twórczej, upodmiotowionej podkreślił Ireneusz Gębski w swojej opowieści W cieniu Sheratona. Przedstawiając obraz polskiej emigracji zarobkowej w Anglii, docenia sukcesy w formie kupna używanego samochodu, przeprowadzki ze wspólnie wynajmowanego mieszkania do własnej klitki, a zwłaszcza znalezienie partnerki. Znamienne jest jednak zakończenie tekstu: „Od tej pory mieli wspólny cel. Oboje wiedzieli, że tylko od nich zależy, czy i jak będą do niego zmierzać..."25. Jest to sygnał zdecydowanego przejścia od wzorca biografii sterowanej czynnikami zewnętrznymi do biografii twórczej, moźliwej do połączenia z wzorcem autonomicznego działania w sferze publicznej.

Decyzję o rozpoczęciu pisania łączą migranci z autorefleksją na temat dramatycznego doświadczenia przerwania ciąłości własnej biografii i utraty kontroli nad spójnością własnych struktur tożsamości, a zatem nagłego doświadczenia życia jako rozwijającego się ciągu anegdot. W skrajnej interpretacji kilku autorów ciąg ten przyjmuje formułę dramatycznej sekwencji narodzin i śmierci. Jacek Ozaist, autor opowiadania Wyspa obiecana, pisze na wstępie swojego tekstu: „tak się składa, że gdzieś po drodze umarłem i teraz rodzę się na nowo"26. Migracyjny motyw ponownych, traumatycznych narodzin wprowadza także Ryszard Adam Gruchawka w powieści Buty emigranta, opowiadającej o pracy na farmie w Irlandii: „Wszyscy bez wyjątku rodzimy się nadzy. Podobnie jest z człowiekiem, który przybywa na obcą ziemię: jest pozbawiony prywatności i poczucia godności"27. I podobnie konstatuje Piotr

24 Schemat taki promują I. Nowak, Opowieść emigracyjna, Wydawnictwo Innowacyjne, Gdynia 2010; A. Łajkowska Miłość na wrzosowisku, Pensjonat nawrzosowisku, Damidos, Katowice 2012a, 2012b; M. Semeniuk Emigrantką być, czyli wspomnienia z Wells, Warszawska Firma Wydawnicza, Warszawa 2011.

I. Gębski Wcieniu Sheratona, s. 162.

1. Ozaist Wyspa obiecana, w: Na końcu świata napisane. Autoportret współczesnej polskiej emigracji, Konkurs Literacki Polish Books, Videograf II, Londyn Chorzów 2007, s. 21. 
Czerwiński w opisach codziennej sytuacji migranta podejmującego walkę o przetrwanie: „rodzisz się-umierasz-rodzisz się-umierasz"28.

Monika Grochalska w opracowaniu Transgresyjne trajektorie. Zmiana statusu spotecznego w perspektywie biograficznej, nawiązując do koncepcji Schütze, podkreśla w założeniach wstępnych funkcję mediacji świata znaczeń między świadomością a doświadczeniem. „Znaczenia tworzone na podstawie doświadczeń" modyfikują pole świadomości i zwrotnie - są znów przez świadomość modyfikowane. Zespoły takich znaczeń tworzą „koncepcje zjawisk”" Autonarracja, jako forma organizacji doświadczeń, prowadzi potencjalnie do skonstruowania „polifonicznego ja”, umoźliwiającego formułowanie nowych, złożonych relacji ze światem ${ }^{30}$. Jakość owego „polifonicznego ja” nie jest aksjologicznie jednoznaczna, co podkreślił Łukasz Suskiewicz, wprowadzając jako motto do opowiadania Nieznośna lekkość stylu, będącego częścią opowieści EgriBikaver, słownikowe hasło „pugurus” w dodatkowym kontekście aksjologizacji praktyk i środowisk twórczych. Pugurus to skorupiak morski z rzędu dziesięcionogów, zajmujący puste muszle ślimaków, by chronić swój miękki workowaty odwłok. Pugurus żyje w symbiozie z osiedlającym się na muszli ukwiałem, gąbką lub kolonią stułbiopławów ${ }^{31}$. Synektyczny obraz skorupiaka to metafora strategii przetrwania w warunkach niestabilnego środowiska, podważającego ukształtowany w dotychczasowej biografii system wartości, także estetycznych.

Praktyka autonarracji jako pytanie o własną tożsamość podtrzymuje, rekonstruuje lub rozładowuje napięcia między wewnętrznym obrazem „ja" i obrazem kształtowanym przez warunki nowego środowiska. Stanowi zarazem o poszukiwaniu wyznaczników tranzytywności między przestrzenią opuszczoną i zakładanym jako czasowe miejscem pobytu. Ton emocjonalny literackiej historii życia nadają wspomnienia z dzieciństwa i zarejestrowane

28 P. Czerwiński Przebiegum życiae..., s. 69.

29 M. Grochalska Transgresvine trajektorie. Zmiany statusu społecznego w perspektywie biograficznej, Impuls, Kraków 2011, s. 14-15.

30 K. Stemplewska-Żakowicz Koncepcje narracyinej tożsamości. Od historii życia do dialogowego "ia", w: Narracja jako sposób rozumienia świata, red. J. Trzebiński, GWP, Sopot 2001, s. 102-107; H. Gasiul Monolog czy dialog? Refleksje nad kryteriami oceny jakości rozwoju "ja", w: Polifonia osobowości. Aktualne problemy psychologii narracii, red. E. Chmielnicka-Kuter, M. Puchalska-Wasyl, Wydawnictwo KUL, Lublin 2005, s. 42-43.

31 L. Suskiewicz Egri Bikaver, Wydawnictwo Forma, Stowarzyszenie OFFicyna, Szczecin-Brzeszcze 2009, 5. 91. 
w pamięci jakości doznań zmysłowych, charakterystycznych dla domu rodzinnego i artefaktów środowiska lokalnego, zwłaszcza miejskiego czy naturalnego pejzażu i klimatu ${ }^{32}$. Twórcy migracyjnych narracji, odróżniając działania doraźnie, priorytetowe, od działań długoterminowych (zakładanych w marzeniach o powrocie do Polski), rozgraniczają wyraźnie codziennośćl sytuacyjność/lokalność i źródłowe (dziecięce, etniczne) miejsca, w których kształtowała się ich biografia. Są równocześnie świadomi, że miejsca te podlegają dynamicznym zmianom, których ponowne zrozumienie zależy od rozwoju indywidualnego każdej z osób ${ }^{33}$. O ile „z okresu dziecięcych zabaw pochodzą główne tendencje motywacyjne wyrażające się dążeniem do siły, władzy, kontroli nad światem i/lub dążeniem do bliskich kontaktów z ludźmi, do tworzenia więzi, relacji pełnych miłości i intymności", to w fazie dorosłości opracowywane są wzorce (imago) dorosłego życia ${ }^{34}$. Podmioty mówiące, proponując sposoby radzenia sobie z rzeczywistością, przedstawiając motywacyjne fabuły, przywiązują także znaczenie do problematyki tożsamości kulturowej, zwłaszcza językowej. „Środowisko semantyczne” i kontekst znaczeniowy umożliwiają tworzenie narracji zanurzonych w pierwotnym kręgu kulturowym i społecznym. „Słowa, jakie poznaje dziecko, komunikując się z najbliższymi, pozwalają mu wyodrębnić pewne całości: rzeczy, cechy, wartości irelacje [...]. Narracja o świecie, o życiu i ludziach, o prawach i prawdach, opowiadana w znacznej mierze językiem etosu rodzinnego, jest transmitowana kolejnym pokoleniom - staje się przekazem międzypokoleniowym, olska karma (Skrzat, Kraków 2007, s. 134) pisze wprost: „Wyjeżdżając z Polski, szukasz je gdzie indziej, bo to twój jedyny, chcesz czy nie chcesz, fundament, język w gębie, którego nie wydrzesz i gleba, na której pierwsze krokistawiałeś. I mimo że wciąż jesteśzły na Polskę, to i tak jest ona jedyną skalą porównawczą i decydującym głosem w sprawie wartości. A kosmopolitę tylko się udaje, bo w głębi duszy pragnie się wrócić do Polski... choćby na starość. Justyna Zbroja w opowiadaniu Jutro zobaczę Polskę lutro zobaczę Polskę, w: Wyfrunęli. Nowa emigracja o sobie, red. W.T. Czartoryska, OW "Stopka", Łomża 2011, s. 320, napisała: "Bardzo chcę wrócić do Polski. Ale do jakiej Polski chcę wrócić? Tej wymyślonej przeze mnie? Wyimaginowanej w bezsennych z tęsknoty nocach? Najpierw muszę spojrzeć na nią bez iluzji. [...]. Zobaczyć i wrócić. Świadomie. [...] Tak trudno jest zostać...Tak trudno jest wrócić". Gosia Brzezińska, dziennikarka, kończąc swoją powieść Irlandzki koktajl, Bliskie, Warszawa 2010, s. 343, pisze w ostatnim zdaniu: "Powrót do domu był jak podróż w nieznane". 
familijną strukturą sensu"35. Utrata spójności języka, jako ślad utraty spójności rodziny i środowiska, to problem redefinicji tożsamości na poziomie językowego obrazu świata, zarówno dorosłych, jak i dzieci. Narratorka Emigrantki z wyboru interpretuje język polski jako „wyjście awaryjne”, „zapasowe dno", „drugą stronę księżyca” - dary, które dziecku zostawi w spadku³6. Silne zakorzenienie w etnicznej pamięci kulturowej buduje synchronicznie umiejętność poruszenia się na pograniczach kulturowych. Wzajemne, świadome postrzeganie siebie przez reprezentantów różnych kultur może stanowić czynnik rozwoju indywidualnego, a zarazem daje szanse na przeżycie własnej tradycji w relacji do napotykanych, charakterystycznych dla odmiennej kultury kontekstów ${ }^{37}$. Ernest Bryll i Małgorzata Goraj-Bryll w dzienniku podróżnym Irlandia, celtycki splot pytają: „Co właściwie nowego mam odkryć, wędrując po mieście i powołując się co rusz na wędrówki Blooma, Dedalusa, Joyce’a? Czy szukam własnego mitu, czy biegnę za czymś, czego odnaleźć się nie da?"38. Łukasz Suskiewicz wpisuje w figurę narratora humanisty szlak kulturowego nomady, który łączy monotonię codziennego poszukiwania pracy z wyprawami do bibliotek i galerii sztuki, z odwiedzinami domu Yeatsa. Lektura Dostojewskiego, Durrella, Becketta, obrazy Caravaggia „smakują” inaczej sytym i bezpiecznym turystom, a inaczej migrantom humanistom pozbawionym środków do życia, dla których stają się podstawową gwarancją biograficznej i aksjologicznej spójności „ja"39.

Unikalnym, ale niezwykle ważnym czynnikiem moźliwej transformacji biografii jest umiejętność zdystansowania się wobec aktualnie przeżywanej rzeczywistości. Umiejętność ta daje podstawę do wewnętrznego przekraczania społecznych uwarunkowań wpisywanych w biograficzne trajektorie, a w efekcie zwiększa opcjonalność wyboru przyszłych działań. Stan takiego „zatrzymania się" dobitnie wyraził Łukasz Suskiewicz w nostalgicznym, melancholijnym obrazie portu w Irlandii, Dun Laoghaire. Przerywając opisy zdarzeń związanych z uporczywymi próbami stabilizacji ekonomicznej, odsłania

35 A. Cierpka Tożsamość jednostki wśród rodzinnych narracji, w: Narracja jako sposób rozumienia świata, red. J. Trzebiński, GWP, Sopot 2001, s. 174, 176.

37 A.M. Radziewicz-Winnicki, M. Walancik Pomiędzy kulturowym uniwersalizmem a narodowa rodzimościq we wzajemnym postrzeganiu, w: Wielka emigracja zarobkowa młodzieży. Wyzwanie dla edukacji, red. R. Bera, Wydawnictwo UMCS, Lublin 2010, s. 51-64.

38 E. Bryll, M. Goraj-Bryll Irlandia, celtycki splot, Zysk i S-ka, Poznań 2010, s. 287. 
nasycone emocjami, uniwersalne doświadczenie bliskości z naturą: „Siadaliśmy na molo, które zwieńczała niewielka latarnia. Przed nami kłębiło się morze, oddychające załamaniami fal. Wiatr przywiewał pojedyncze krople. Gdzieś daleko w mroku chwiało się blade światełko, które czasem zbliżało się, a czasem oddalało [...]. Deszcz, który spływał po twarzy, nie dokuczał. Wokoło szalały stada mew. Nie mogę zapomnieć tamtej chwili"40.

\section{Wnioski}

Zdaniem Fritza Schütze, jeśli mechanizmy trajektorii biograficznych mają charakter negatywnego sprzężenia zwrotnego, błędnego koła, to przyjmują postać mniej lub bardziej systematycznej pułapki. Doświadczenie „pułapki” prowadzi do przekształceń wyjściowego cierpienia w inne obszary problemowe. Schütze wyróżnia trzy poziomy tego rodzaju przekształceń: poziom quasi-metafizyczny (zwłaszcza próby przekształcenia chaosu w porządek, nad którym podmiot może sprawować częściową kontrolę), poziom interakcyjny i poziom zmian tożsamości ${ }^{41}$. Wszystkie te przekształcenia są znamienne w autonarracjach polskich migrantów, a ich sygnaturą stają się specyficzne działania renormalizacyjne w formie krytycyzmu wobec aksjologicznych jakości konstytuujących symboliczne uniwersum globalnego społeczeństwa, takich jak „barbarzyńska siła pieniądza”, seks, prymitywizm zachowań i postaw, kreowanie potrzeb w multimedialnej komunikacji masowej, uwodzenie jako norma powszechnych interakcji publicznych, symulacja faktów, hedonizm wyobrażeniowy (Suskiewicz, Czerwiński, Wojnarowski, Gruchawka, Parys-White, Zimny-Louis).

Zdecydowana większość autonarracyjnych praktyk ma charakter takich aktów performatywnych, w których istotne są zbiory znaczeń, sens przekazu i jego funkcja komunikacyjna, swoiste „zaświadczenie” przeżytych zdarzeń. Pisanie jest dla autorów ekspresją prymatu spontanicznego, twórczego „ja” nad postawą reprezentacji, wymagającą szczególnych kompetencji artystycznych i estetycznych. Performatywne strategie komunikacji jako „świadectw" łączą się szerzej z problematyką ponowoczesnych communitas, wspólnot etnicznych, artystycznych, wyobrażeniowych, społecznych, informacyjnych kształtujących nowy typ relacji do struktur oficjalnych czy porządków systemowych. Jedną z podstawowych cech communitas jest także immanentne

\footnotetext{
40 Tamże, s. 43.

41 F. Schütze Trajektorie cierpienia, s. 46-47
} 
formułowanie nowych tożsamości kolektywnych, a w ich wnętrzu specyficznych tożsamości dla „ja”. Victor Turner, analizując liminalną strukturę communitas, podkreśla, że wspólnoty takie są spontaniczne i samorodne, wyzwalają skrytą w ludziach siłę i funkcjonalizują kontrdyskursy wobec wszelkich innych communitas ${ }^{\mathbf{4 2}}$.

Procesy indywidualnego i zbiorowego redefiniowania świata przez polskich pisarzy-migrantów, łącząc się z przemianami w sferze społecznej i ekonomicznej, oraz analiza aktualnych przestrzeni tranzytywnych i liminalnych, funkcjonalizują strategie negocjowania toźsamości jako fundamentalną praktykę przetrwania. Ramy uniwersum symbolicznego stanowią wich narracjach o typizacji wartości i podmiotów uniwersum, sterujących systemem społecznych oczekiwań. Równocześnie ramy te dopuszczają indywidualizację sygnatury „ja”. Reguły interakcji, kooperacji i komunikacji są podporządkowane podstawowym wyobrażeniom narratorów na temat projektów biograficznych i ich konkretnych realizacji. Symboliczna interakcja, odzwierciedlana w autonarracjach, dostarczając autorom podstawowych sposobów interpretacji grup i jednostek, umoźliwia uchwycenie sensu działań i modyfikacji kierunku własnych przemian. Zawartość uniwersum symbolicznego kształtują dynamicznie różnicowane (harmonizowane, negocjowane) kierunki progresji. Aksjologizacja składników symbolicznego uniwersum i jego proaktywne w narracjach odzwierciadlenia w przywoływanych tutaj tekstach są najczęściej łączone z sygnaturami pożądanych dóbr - jednak nie tylko ekonomicznych, ale także emocjonalnych, rodzinnych i przechowywanych w pamięci kulturowej jako dobro i doświadczenie (często traumatyczne) wspólnoty etnicznej.

42 V. Turner Gry społeczne, pola i metafory. Symboliczne działanie w społeczeństwie, przeł. W. Usakiewicz, Wydawnictwo UJ, Kraków 2005, S. 195-228. Rozwinięcie tego nawiązania proponuję w: J. Ślósarska Między "ja" a tożsamością kolektywnq w tekstach polskich migrantów przebywajacych w Wielkiej Brytanii i Irlandii po roku 2004, "I rydion” 2015 nr 1, S. 234-235. 


\section{Abstract}

\section{Joanna Ślósarska}

UNIVERSITY OF ŁÓDŹ

Self-Narration as a Strategy of Negotiating Identity in the Texts of Polish Migrants Residing in the UK and Ireland after 2004

The article explores the shaping of narrators' polyphonic identities in texts produced by Polish migrants temporarily residing in the UK and Ireland. Examining dozens of works produced between 2004 and 2015, ślósarska tackles identity in relation to the fundamental determinants of self-narrative strategies. Her methodology is rooted in symbolic interactionism, standard patterns of biographies, and self-narration as a way of understanding and interpreting the world. Her conclusions focus on the function of self-narration in reconstructing individual and ethnic identities by migrants looking for new patterns of adaptation in unstable existential situations; the axiologization of the new experiences is discussed in relation to ethnic cultural memory and to the social and family identity roles developed earlier in life.

\section{Key words}

migration, self-narration, biographical trajectory, individual identity 